\title{
Pierre Robin Syndrome
}

National Cancer Institute

\section{Source}

National Cancer Institute. Pierre Robin Syndrome. NCI Thesaurus. Code C85010.

A rare congenital malformation characterized by micrognathia, posterior retraction of the tongue, and cleft palate. 